\title{
Gender factor in hematopoietic stem cell transplantation
}

\author{
Alexei B. Chukhlovin \\ Raisa Gorbacheva Memorial Research Institute of Pediatric Oncology, Hematology and Transplantation, Pavlov University, \\ St. Petersburg, Russia
}

Prof. Alexei B. Chukhlovin, Raisa Gorbacheva Memorial Research Institute of Pediatric Oncology, Hematology

and Transplantation, Pavlov University, L. Tolstoy St. 6-8, 197022, St. Petersburg, Russia
Phone: +7 (921) 3250094

E-mail: alexei.chukh@mail.ru

Citation: Chukhlovin AB. Gender factor in hematopoietic stem cell transplantation. Cell Ther Transplant 2020; 9(1): 13-21.

\section{Summary}

There is a huge number of studies concerning metabolic, immunological and other differences between males and females caused by their differential hormonal and physiological background. However, only few studies are dedicated to sex-dependent differences in amounts of donor hematopoietic cells used for stem cell transplantation (HSCT), kinetics of cytostatic drugs used for conditioning treatment and immunosuppressors for GvHD prophylaxis, as well as differences in common posttransplant complications. The following differences significant for evaluation of HSCT results may be derived from previous studies: (1) Higher counts of CD34+ cells in hematopoietic grafts from males compared to female donors; (2) Metabolism of cytostatic drug in females suggest a tendency for decreased clearance and higher modification rates due to increased CYP3A activities, along with decreased drug efflux from target cells, thus suggesting higher accumulation of active cytostatic metabolites in female patients; (3) More effective and stable humoral immune response in females compared to males could be translated into better anti-infectious response, along with higher risk of chronic GvHD in females after allo-HSCT; (4) Male patients with some hematological malignancies subjected to allo-HSCT are more prone to posttransplant relapses, however, conflicting data are reported; (5) Increased risk of acute GvHD in males exists in cases of allo-HSCT from female donors. The issue of graft-versus-leukemia effect in this setting still remains open. In sum, estrogen hormones seem to be to the most probable cause of gender differences in HSCT-associated risks. However, modifying role of sex steroids is not well studied, and it should vary, depending on the age of patients. Therefore, real significance of sex differences in HSCT deserves further extensive studies in large databases.

\section{Keywords}

Hematopoietic stem cell transplantation, sex differences, drug kinetics, immune response, GvHD, relapses, survival, estrogens, outcomes.

\section{Hematopoietic cell counts in peripheral blood}

Some data exist concerning HPC contents in peripheral blood. In an early study, semisolid methyl cellulose-based clonogenic cultures were assayed in 43 healthy volunteers including 22 males and 21 females at the age of 21 to 39 years old [1]. Comparative studies have shown increased numbers of colony-forming cells (CFC), erythroblastic progenitors (BFU-E), and non-differentiated myeloid precursors (GM$\mathrm{CFU}$ ) in peripheral blood (PB) in male individuals. However, the numbers of pluripotent CFU-GEMM in peripheral blood did not differ between females and males. Probable effects of sex steroids on these cell populations still remain open.

A more recent study from USA was carried out in a large cohort of 1786 Framingham Heart Study participants who underwent counting of CD34(+) cells in peripheral blood [2]. Among 1595 persons without cardiovascular diseases, CD34(+) frequency tended to decrease with older age and in females, thus suggesting higher numbers of peripheral hematopoietic cells in males.

Sex differences in circulating HSC subpopulations were also found in a group of 642 persons (mean age, 48 years) 
either healthy, or with cardiovascular disorders [3]. CD34+ $\mathrm{CD}^{45 \mathrm{med}+}$ and some other HSC markers were determined by flow cytometry. After adjustment for age, cardiovascular risk, and body mass, the individual counts for $\mathrm{CD}_{3} 4^{+}$, $\mathrm{CD} 34^{+} / \mathrm{CD} 133^{+}$, and $\mathrm{CD} 34^{+} /$chemokine receptor $4+$ counts, were found to be lower in women than in male persons.

Thus, one may consider higher background counts of hematopoietic stem cells in HSC grafts from males compared to female donors.

The potentially higher amounts of hematopoietic stem cells in males may be translated into higher incidence of hematological malignancies, i.e., CML (and, probably, of chronic myelomonocytic leukemia) in male persons rather than in females, as shown in a big cohort, e.g., Hiroshima survivors observed over decades [4]. The authors consider two hypotheses: increased actual risk for this disorder, or shorter latency time in males needed for development of the disorder

\section{Gender differences in pharmacokinetics}

\section{Cytostatic drugs, CYPs and pGp effects}

Intensive conditioning treatment is a basic pre-requisite of hematopoietic stem cell transplantation procedure. In leukemia treatment, it is intended for eradication of malignant cells, as well as for engraftment and proliferation of donor hematopoietic cells. Therefore, sex-specific effects of cytostatic drugs should be realized when planning optimal conditioning protocols. Studies of these sex differences in response to the common cytostatic drugs, generally, show that female patients are, generally, more stable than males, and moreover, depend on the type and dose of cytostatic agent applied [5].

Influence of gender may be exerted at different steps of drug processing in the body, i.e., absorption, distribution, metabolism (mainly in gut and liver), and excretion, corresponding to the ADME concept. Among other cytostatics used during HSCT, a decreased clearance of MTX, etoposide, doxorubicine and melphalan was found in women. Prolonged halflife was reported for different therapeutic antibodies, e.g., widely used Rituximab [6]. E.g., intersexual differences in equivalent doses of steroid drugs are readily explained by their more rapid metabolization (mostly activation) in women caused by sex-dependent CYP3A4 expression in liver [7].

An early well-known study by Hunt et al. [8] showed a significant increase of CYP3A activity (assessed by erythromycin demethylation) in liver tissues from normal females compared to males. Meanwhile, Wolbold et al. [7] reported 2-fold increase in CYP3A levels in females accompanied by $50 \%$ increase in the CYP3A measured as verapamil conversion rates. As reviewed by Fujita [9], there are numerous CYP3A substrates among anticancer drugs used in oncohematology, e.g. cyclophosphamide, taxanes, tyrosine kinase inhibitors etc.

At the present time, most authors agree that CYP3A4 expression and function in the liver of females is higher than in male persons [10]. However, the CYP3A4 activity is sup- pressed in acute inflammation and subject to unpredictable changes in cases of multiple drugs used in HSCT practice. Therefore, its role in pharmacokinetics requires special evaluation in cases of acute tissue damage, such as intensive anticancer therapy [11].

P-glycoprotein, is another potent modifier of drug effects. It is an important tool for the drug efflux from target cells [12]. Worth of note, most drugs metabolized by CYP3A4 in liver, are also subjected to P-glycoprotein-mediated efflux from the cells, thus providing a dual pharmacodynamic effect. Interestingly, the drug efflux could be reduced in females due to lower expression of P-glycoprotein in liver cells [13].

In general, available data on drug metabolism in females suggest an evidence for decreased clearance, higher activation rates due to increased CYP3A enzyme activities, and decreased drug efflux from liver cells, thus suggesting higher accumulation of active cytostatic drugs in the body, thus being predisposed to more expressed cytotoxicity towards malignant cells and normal tissues. However, individual gender-based drug dosage is not possible, due to drug interactions, genetic polymorphisms (e.g., CYP3A4) and other numerous factors modifying the effects of metabolizing enzymes and p-glycoprotein.

\section{Immune suppressor drugs}

Immune suppressor drugs used in post-transplant period usually affect cellular immunity, mostly, T cell populations. Some data about sexual dimorphism of their effects are obtained from studies in organ transplantation. E.g., the impact of gender on survival of renal allografts was thoroughly discussed in a review by Momper et al. [14]. Some controversies on sex differences in renal transplant survival that could be partly explained by the patients' age, due to differential hormonal patterns at pre-puberty and post-menopause periods of life.

Whatever the exact mechanisms, calcineurin inhibitors (cyclosporine and tacrolimus), generally, used in posttransplant patients exhibited higher clearance rates in women than in males $[15,16]$.

Similar increase of sirolimus clearance in females as compared with males was shown elsewhere [17]. This difference may be again coupled to the mentioned CYP3A and P-glycoprotein alterations in women.

By contrary, mycophenolic acid (MPA) is also commonly used in post-transplant patients. Appropriate studies in a group of 100 renal transplants have showed a significantly increased MPA kinetics in males against females, due to higher glucuronate conjugation of MPA in male patients [18]. Indeed, the in vitro studies have shown that the liver samples in men exhibited a 3 to 4 -fold higher gene expression and microsomal activity levels for UGT2B17 conjugating enzyme compared to women [19]. A conclusion could be made that the observed sex-dependent differences in pharmacokinetics of immunosuppressor drugs occur due to main metabolic mechanisms, i.e., drug efflux or conjugation via common liver enzymes. 
Gender differences for glucocorticoid kinetics were intensively studied over last 25 years. Female sex is, generally, associated with lower clearance and, therefore, increased prednisolone exposure, as reviewed by Momper et al. [14]. Indeed, total body weight-normalized free prednisolone oral clearance was shown to be higher in men $v s$ women [20], regardless of race (by $22 \%$ in whites and $40 \%$ in blacks for oral clearance, $\mathrm{p}<0.01)$.

Thus, clearance of different immune suppressors in women is higher for cyclosporin A, tacrolimus and sirolimus, whereas clearance of MPA and glucocorticoids is higher in males, probably, due to different conjugation mechanisms of specific drugs.

\section{Infections and immune response}

A number of works have demonstrated lesser risks for severe posttraumatic infections and multiple organ failure in females. Most of these studies were performed in experimental models [21].

In a seminal large multicentric study involving 20.000 post-traumatic patients, the significant survival benefit was shown for female patients younger than 50 years [22]. In later studies, significantly better outcome was revealed for women after traumatic injury, severe blood loss and sepsis. Better survival of females in these settings are thought to be mediated via sex hormone effects and in particular, estrogen binding to their specific cell receptors [23].

Most clinical and experimental studies suggest increased immunoreactivity, especially, humoral response in females compared to males [24].

At the average, innate and adaptive immune response in females is higher than in, thus resulting in lesser susceptibility to bacterial, fungal and viral infections, however more predisposed for autoimmune conditions [25]. Both genetic factors and hormonal molecules contribute independently to gender differences in immune response. Some immune-related genes are located on the $\mathrm{X}$ chromosome, thus determining lesser immune response in young males. At later ages, estrogen and testosterone become the major regulators of immune cell kinetics, their maturation and functions. Thus, sexual dimorphism may cause significant differences in occurrence of infectious or autoimmune diseases between females and males.

A number of studies have shown higher antibody responses and longer half-life of immunoglobulins in females (e.g. following vaccination) that are extensively discussed by Fischinger et al. [26]. Vice versa, innate immunity and NK activity seem to be increased in males.

Some experimental and clinical studies have shown that the ratio of different IgG subclass can vary between in sex-specific manner. E.g., Simon et al. [27] have revealed that females during cytomegalovirus (CMV) infection produce higher levels of IgG3, the most active antibody subclass. Moreover, as shown by oncologists, female patients respond more effectively to rituximab treatment, probably, due to slower clearance and longer half-life of the antibody-based drugs [28].
Aiming for space economy, we cannot extensively discuss clear sex differences in gut microbiome that was already discussed by Ruggieri et al. [29]. The numerous bacteria inhabiting normal microbiome may both metabolize sex hormones and produce antigenic landscape for optimal antibody response.

When studying intestinal biopsies in healthy persons, women had higher levels of immune activation and inflammation-related gene expression in gut mucosal samples [30], as well as significantly higher levels of immune activation-associated phenotype of CD4+ and CD8+ T cells from peripheral blood.

Higher humoral immune response to viruses in female HSCT patients was confirmed in several works. E.g., an extensive HSCT population was studied by Ljungman and Brandan [31]. To study factors determining CMV status, 40.311 patients and 23.048 donors were identified in the EBMT registry. Female patients were more likely to be CMV-seropositive $(p<0.001)$. Adjusted for patient serostatus, the risk of a donor being seropositive was higher in females $(\mathrm{p}<0.001)$ and in older donors $(\mathrm{p}<0.001)$.

Hence, a more effective immune response may be observed in females compared to males. This difference may be explained by dominant effects of female steroid hormones which seem to exert mostly proinflammatory effects, whereas androgens exerting immunomodulatory properties. Most sex-dependent immune differences observed in males and females, i.e, lower response to infection and vaccination in males, or the higher incidence of autoimmunity seen in females, are ascribed to female steroid hormones which seem to exert mostly proinflammatory effects [32].

There is controversial information on rates of viral infections. As expected, male sex was shown to be the risk factor for BK virus infection following organ transplantation [33]. On other hand, as shown by Freeman et al. [34], female sex was proven to be associated with CMV disease in solid organ transplants (OR, 2.19; 95\% CI 1.21, 3.99) and CMV viremia (OR, 1.65; 95\% CI 1.03, 2.65).

Therefore, active treatment with antiviral drugs is often required in cases of viral activation. Sex-dependence of antiviral drug kinetics is poorly studied. E.g., transport of these drugs to renal tubules is controlled, e.g., by organic anion 1 (OAT1), an efflux transporter at the membranes of renal proximal tubules [35]. A higher ganciclovir clearance $(+24 \%)$ was previously shown for female patients.

\section{GvHD incidence}

Concerning frequency and severity of acute GvHD in male $v s$ female recipients of allografts, most studies did not show any sex differences incidence or severity when comparing male and female patients. The only condition associated with more common aGvHD and inferior survival is transplantation of female HSCs transplanted to male recipients, e.g., see Inamoto et al. [36]. In this study, GvHD- and relapse-free survival was assessed at 1 year post-HSCT based on 23.000 cases of first transplants. It was associated with some factors, including, anti-thymocyte globulin prophylaxis (for standard- 
risk-disease), recent years of transplantation etc. Better survival was observed with sex combinations other than from a female donor to a male patient. Therefore, female-to-male grafting was found to be of maximal risk for the male patients.

Meanwhile, prevalence of chronic GvHD showed a more distinct dependence on the donor gender. In an early study by Locatelli et al. [37], a group of 145 patients with acute GCHD and 114 cases at risk for chronic GvHD. Of them, 107 (74\%) presented with acute GvHD (of them, grade II-IV developed in 35\%). I.e., the incidence of chronic GvHD was higher in female-to-male than in male-male donor-recipient sex pairs $(33 \%$ vs $11 \%, \mathrm{p}<0.05)$, with no difference between female-to-female and male-to-female pairs. In patients of $>10$ years old, a higher incidence of chronic GvHD was observed in both female donors and recipients compared with male donors and recipients (48\% vs $20 \%$ and $47 \%$ vs $19 \%$, respectively, $\mathrm{p}<0.05)$.

Possible role of female donorship for chronic GvHD was also suggested for patients reported by Gaziev et al. [38]. Several risk factors included grade I-IV acute GvHD, prior aGvHD ( $\mathrm{p}=0.000)$, female donor sex $(\mathrm{p}=0.000)$, use of alloimmune female donors for male patients $(0.009)$ that predicted chronic GvHD.

Reduced salivary function (dry mouth) is a common sign of chronic GvHD developing after allo-HSCT. A total of 74 adolescents received allo-HSCT and conditioning with busulfan or total-body irradiation [39]. In the multivariate model, only female sex was significantly correlated with low salivation rates several years later.

Therefore, donor/recipient sex differences, along with other biological factors, were still under discussion if compared to dominant influence of, e.g., HLA matching which may control the HCST outcomes, as suggested by Confer et al. [40]. In cases of several available donors, one may select them for age, sex, parity, cytomegalovirus (CMV) serostatus, ethnicity and $\mathrm{ABO}$ blood type.

\section{Relapses and overall survival}

Solh et al. [41] analyzed medical histories for 389 post alloHSCT patients who survived and were disease-free for at least one year post-transplant, with a median follow-up of 48.2 months. The median 5-year OS overall survival and DFS at 5 years were 78 and $74 \%$, respectively. The most common causes of late mortality were high-risk disease and relapses, chronic GvHD, infections, and male sex. The risk factors for late relapse included male sex and high/very high disease risk index.

Another Turkish study [42] was performed in 193 patients with CML subjected to allo-HSCTs between 1989 and 2012 (before and after TKI advent). Despite quite different clinical state at HSCT, the rates of hematologic remission at 3 months after allo-HSCT were similar between TKI and pre-TKI eras, the patients having remission had better disease-free survival. Interestingly, male allo-HSCT recipients had worse DFS and OS (RR: 1.7, p=0.007) than females.
Sex differences are also shown for late outcomes of auto- and allo-HSCTs in r/r Hodgkin's lymphoma by Japanese workers [43]. They treated 298 and 122 patients, respectively. For both autologous and allogeneic HSCT, overall 3-year survival was dependent on sex, and performance status (PS) at HSCT. Following $1^{\text {st }}$ allo-HSCT, female sex at HSCT was significantly associated with better progression-free survival $[\mathrm{RR}=0.55(0.32-0.94)]$.

In a comprehensive study by Schmid et al. [44], clinical efficiency of donor lymphocyte infusions was evaluated in 399 AML cases after allo-HSCT (of them, 228 DLI-treated patients), with a median follow-up of 27-40 months, respectively. Estimated survival at 2 years (+/- standard deviation) was $21 \%+/-3 \%$ for patients receiving DLI and $9 \%+/-2 \%$ for patients not receiving DLI. Among DLI recipients, female sex $(\mathrm{p}=0.02)$, along with lower tumor burden, were predictive for survival in a multivariate analysis.

Early clinical works on sex differences in HSCT outcome male-female differences in HSCT were presented by Gratwohl et al. [45]. The authors analyzed clinical outcomes of HSCT from HLA-identical female donors for 782 patients (438 males and 344 females) with chronic myeloid leukemia (chronic phase). The risk of transplant-related mortality (TRM) and relapse incidence (RI) were compared for male and female recipients at early period (up to 3 months), and at later times (up to 2-5 years post-transplant). Non-relapse-related mortality risk over 5 years proved to be significantly increased in male patients than in females $(42 \% v s$ $27 \% ; \mathrm{p}=0.02$ ), however, without detectable summary effect on relapse incidence. There was no difference in mortality and relapse rates at early terms (0 to $3 \mathrm{mo}$ ) (zero to three months). Meanwhile, the risk of CML relapse was shown to be diminished in male patients; this difference became detectable only after two years of observation $(\mathrm{p}=0.01)$.

A summary of clinical studies showing different outcomes of HSCT in females $v s$ male patients is presented in Table 1.

Hence, one may suggest that male patients with hematological malignancies subjected to allo-HSCT are more prone to posttransplant relapses and late mortality.

\section{Female-to-male grafting: Y-encoded antigens?}

Consequences of sex-mismatched HSCT and role of male minor antigens in hematopoietic transplantation were discussed for decades as a factor of HSCT outcomes. E.g., sex chromosome-linked minor histocompatibility determinants have been shown to affect the incidence and severity of graftversus-host disease (GvHD) in both humans and animals [46]. On the basis of earlier studies done in mice and humans, it has often been assumed that this effect is due to a simple response of female donor cells recognizing recipient male HY antigens as foreign and reacting against them.

Minor histocompatibility antigens (mHAs) recognized by donor $\mathrm{T}$ cells play a central role as immunologic targets of graft-versus-host disease (GvHD) and graft-versus-leukemia after allogeneic hematopoietic stem cell transplantation 
Table 1. Gender differences in survival and/or relapse rates for the patients subjected to allo- or allogeneic HSCT

\begin{tabular}{|c|c|c|c|c|c|}
\hline $\begin{array}{l}\text { Primary } \\
\text { disorder }\end{array}$ & Number of cases & Donor type & Outcome & $\begin{array}{l}\text { Difference revealed, } \\
O R, p\end{array}$ & Reference \\
\hline $\begin{array}{l}\text { ALL, AML, CML, } \\
\text { NHL, HD }\end{array}$ & 389 (m214) & $\begin{array}{l}\text { MRD, MUD, } \\
\text { Haplo }\end{array}$ & $\begin{array}{l}\text { Relapse risk beyond } \\
1 \text { year }\end{array}$ & $\begin{array}{l}\text { Males > females: } \\
\text { HR-1.87; } p=0.02\end{array}$ & Solh et al., 2018 \\
\hline CML & 193 (112m, 81f) & $\begin{array}{l}\text { MRD (185), } \\
\text { MUD (8) }\end{array}$ & Shorter DFS & $\begin{array}{l}\text { Males > females: } \\
\text { RR:1.7, } p=0.007\end{array}$ & Özen et al., 2017 \\
\hline HD & 298 auto, 122 allo & $\begin{array}{l}\text { MRD (47), } \\
\text { MMR (20), } \\
\text { MUD (40), } \\
\text { Cord bood (11) }\end{array}$ & $\begin{array}{l}\text { 3-year progres- } \\
\text { sion-free survival }\end{array}$ & $\begin{array}{l}\text { Females > males: } \\
\text { RR: } 0.55 \text { (0.32-0.94), } \\
p=0.03\end{array}$ & Kako et al., 2015 \\
\hline $\begin{array}{l}A M L \text {, post-HSCT } \\
\text { relapse }\end{array}$ & $\begin{array}{l}228 \text { allo-HSCT+DLI, } \\
139 \mathrm{~m}, 89 \mathrm{f}\end{array}$ & MRD, MUD & $\begin{array}{l}\text { 2-year overall } \\
\text { survival after DLI }\end{array}$ & $\begin{array}{l}\text { Females > males: } \\
\text { RR 1.6 (1.1-2.4), } \mathrm{p}=0.02\end{array}$ & Schmid et al., 2007 \\
\hline CML & $438 m, 344 f$ & MRD, MUD & $\begin{array}{l}\text { Non-relapse-related } \\
\text { mortality over } 5 \\
\text { years }\end{array}$ & $\begin{array}{l}\text { Males }>\text { females } \\
(p<0.02)\end{array}$ & Gratwohl et al., 2001 \\
\hline $\begin{array}{l}\text { ALL, AML, CML, } \\
\text { NHL, HD }\end{array}$ & $562 \mathrm{~m}, 406 f$ & $\begin{array}{l}\text { MRD, MUD, } \\
\text { Haplo }\end{array}$ & $\begin{array}{l}\text { Relapse/progression } \\
\text { rates beyond } 1 \text { year }\end{array}$ & $\begin{array}{l}\text { Females }>\text { males } \\
(p<0.02)\end{array}$ & Own data (2019) \\
\hline
\end{tabular}

(HSCT). Men who have undergone sex-mismatched allogeneic HSCT are at high risk for GvHD because of immune responses directed against mHAs encoded by antigens encoded by some $\mathrm{Y}$ chromosome genes [47].

Higher GvL effects associated with female donors were suggested by Randolph et al. [48] based on analysis of 3238 patients who were subjected to HLA-identical HSCT from siblings. As shown in a large sample of HLA-identical HSCTs, the male patients transplanted from female donors showed higher chances for clinical GvHD, but significantly lower incidence of malignancy relapse. The "graft-versus-leukemia" effect in female-to-male HSCT seems to be independent from GvHD in the cases of acute leukemias and chronic myeloid leukemia. Thus, possible role of H-Y minor male antigens in GvHD could be suggested.

A clinical study by Alhashim et al. [49] was performed in a group of patients with AML in complete remission (215 cases) after allo-HCT from matched siblings, after myeloablative conditioning. Seventy-seven (35.8\%) patients experienced disease relapse, 45 had BMR, and 32 had extramedullary relapses (EMR). Male sex was the only variable that was statistically associated with EMR post allo-HCT, with odds ratio of $3.2(\mathrm{p}=0.01)$.

Recent work by Ayuk et al. [50] was aimed for searching potential HLA-related and non-HLA factors impacting overall survival in general HSCT practice. The authors observed 3215 HSCTs performed between 2005 and 2013 in Germany for acute myeloid leukemia (AML) or myelodysplastic syndrome (MDS). Their donors were HLA-matched related (MRD; $\mathrm{n}=872$ ) or unrelated (10/10 MUD, $\mathrm{n}=1553$ ) or HLA-mismatched unrelated ( $<10 / 10$ MMUD, $\mathrm{n}=790)$. Among non-HLA related factors, age, sex mismatching (male recipient-female donor), and cytomegalovirus (CMV) mismatching (positive recipient-negative donor) seem to influence overall survival. Their adverse effects may be comparable with a single HLA antigen mismatch.

Hence, an increased risk for acute GvHD is observed in cohorts with female-to male HSCT. Association with graft-versus-leukemia effect in these donor-recipient pairs is not proven.

\section{Sex hormones as potential modi- fiers of HSCT-associated events}

In this respect, experimental animal studies have demonstrated that a single, small-volume infusion of ethinyl estradiol-3-sulfate (EES) has beneficial effects following trauma-hemorrhage, even in the absence of fluid resuscitation [51].

It was demonstrated that estradiol treatment exerted these effects via estradiol receptors then being able to downregulate proinflammatory cytokine cascade and intracellular oxidative damage following experimental trauma/hemorrhage [52].

In fact, administration of extradiol in experimental trauma/ hemorrhage was associated with reduced TNF- $\alpha$ and increased IL-10 in affected rats [53].

Hence, the survival rates in sepsis may be, in principle, improved by estrogen administration [54]. Vice versa, blockade of male sex hormone receptors by antagonist drugs is also suggested to boost immune responses in complicated sepsis.

Similarly, treatment with luteinizing hormone release hormone (LHRH) after allo-HSCT in murine experiments caused an enhanced thymic reconstitution and better $\mathrm{T}$ cell recovery, predominantly, among in naive $\mathrm{T}$ cell populations, with increased $\mathrm{T}$ cell functions in vivo and in vitro [55]. Since 
LHRH provides sex steroid ablation (a decrease in luteinizing hormone and follicle-stimulating hormone production, causing a decrease in gonadal sex steroid production) it may represent a promising therapy for enhancement of immunity in secondary immunosuppression. However, these experiments were performed with female mice only.

\section{Conclusion and future prospects}

1. Higher proliferative activity of hematopoietic cells of males could be demonstrated by several independent studies, causing increased background counts of hematopoietic stem cells in HSC grafts from males compared to female donors.

2. Metabolism of cytostatic drug in females suggest a tendency for decreased clearance and higher activation rates due to increased CYP3A activities, along with decreased drug efflux from target cells, thus suggesting higher accumulation of active cytostatic drugs in the body.

3. More effective and stable immune functions, especially, more active antibody response is shown in females compared to males. In allo-HSCT setting, this difference may be translated into higher risk of chronic GvHD in female patients after allo-HSCT.

4. One may suggest that male patients with hematological malignancies subjected to allo-HSCT are more prone to posttransplant relapses and late mortality.

5. A number of extensive studies have shown increased risk of acute GvHD in cases of female-to male HSCT. The issue of graft-versus-leukemia effect in this donor-recipient pairs still remains open.

6. Estrogen hormones seem to be to most probable cause of gender-dependent HSCT-associated events. However, their modifying role should vary, depending on the age of patients. Therefore, age dependence of sex differences in HSCT deserves further studies.

\section{Conflicts of interest}

Non declared.

\section{References}

1. Hörner S, Pasternak G, Hehlmann R. A statistically significant sex difference in the number of colony-forming cells from human peripheral blood. Ann Hematol. 1997;74(6):259-263.

2. Cohen KS, Cheng S, Larson MG, Cupples LA, McCabe EL, Wang YA, Ngwa JS, Martin RP, Klein RJ, Hashmi B, Ge Y, O'Donnell CJ, Vasan RS, Shaw SY, Wang TJ. Circulating $\mathrm{CD} 34(+)$ progenitor cell frequency is associated with clinical and genetic factors. Blood. 2013;121(8):e50-6. doi: 10.1182/blood-2012-05-424846.

3. Topel ML, Hayek SS, Ko YA, Sandesara PB, Samman Tahhan A, Hesaroieh I, Mahar E, Martin GS, Waller EK, Quyyumi AA. Sex Differences in Circulating Progenitor Cells. J Am Heart Assoc. 2017; 6(10). pii: e006245. doi: 10.1161/JAHA.117.006245.
4. Radivoyevitch T, Jankovic GM, Tiu RV, Saunthararajah Y, Jackson RC, Hlatky LR, Gale RP, Sachs RK. Sex differences in the incidence of chronic myeloid leukemia. Radiat Environ Biophys, 2014; 53 (1): 55-63.

5. Schmetzer O, Floercken A, Sex differences in the drug therapy for oncologic diseases. Handb Exp Pharmacol. 2012; 214: 411-442.

6. European Medicines Agency (EMA): http://www.ema. europa.eu.

7. Wolbold R, Klein K, Burk O, et al. Sex is a major determinant of CYP3A4 expression in human liver. Hepatology. 2003; 38(4):978-988.

8. Hunt CM, Westerkam WR, Stave GM. Effect of age and gender on the activity of human hepatic CYP3A. Biochem Pharmacol. 1992; 44(2):275-283.

9. Fujita KI. Cytochrome P450 and anticancer drugs. Curr Drug Metab. 2006; 7:23-37.

10. Bebawy M, Chetty M. Gender differences in P-glycoprotein expression and function: effects on drug disposition and outcome. Curr Drug Metab. 2009; 10(4) 322-328.

11. Kacevska M, Robertson GR, Clarke SJ, Liddle C. Inflammation and CYP3A4-mediated drug metabolism in advanced cancer: impact and implications for chemotherapeutic drug dosing. Exp Opin Drug Metab Toxicol 2008; 4 (2): 137-149.

12. Benet LZ, Cummins CL et al (2004) Unmasking the dynamic interplay between efflux transporters and metabolic enzymes. Int J Pharm 277(1-2):3-9.

13. Schuetz EG, Furuya KN, Schuetz JD. Interindividual variation in expression of P-glycoprotein in normal human liver and secondary hepatic neoplasms. J Pharmacol Exp Ther. 1995, 275(2): 1011-1018.

14. Momper JD, Misel ML, McKay DB. Sex Differences in Transplantation. Transplant Rev. 2017; 31(3):145-150.

15. Bleck JS, Thiesemann C, Kliem V, et al. Diltiazem increases blood concentrations of cyclized cyclosporine metabolites resulting in different cyclosporine metabolite patterns in stable male and female renal allograft recipients. $\mathrm{Br} \mathrm{J}$ Clin Pharmacol. 1996; 41(6):551-556.

16. Velickovic-Radovanovic R, Mikov M, Paunovic G, et al. Gender differences in pharmacokinetics of tacrolimus and their clinical significance in kidney transplant recipients. Gender Med. 2011; 8(1):23-31.

17. Zimmerman JJ. Exposure-response relationships and drug interactions of sirolimus. The AAPS journal. 2004; 6(4):e28.

18. Morissette P, Albert C, Busque S, St-Louis G, Vinet B. In vivo higher glucuronidation of mycophenolic acid in male than in female recipients of a cadaveric kidney allograft and under immunosuppressive therapy with mycophenolate mofetil. Ther Drug Monit. 2001; 23(5):520-525.

19. Gallagher CJ, Balliet RM, Sun D, Chen G, Lazarus P. Sex differences in UDP-glucuronosyltransferase 2B17 expression 
and activity. Drug Metab Disposition. 2010; 38(12):22042209.

20. Magee MH, Blum RA, Lates CD, Jusko WJ. Prednisolone pharmacokinetics and pharmacodynamics in relation to sex and race. J Clin Pharmacol. 2001; 41(11):1180-1194.

21. Bösch F, Angele MK, Chaudry IH. Gender differences in trauma, shock and sepsis. Military Medical Research (2018) 5:35 doi: 10.1186/s40779-018-0182-5-PDF.

22. Wohltmann CD, Franklin GA, Boaz PW, Luchette FA, Kearney PA, Richardson JD, et al. A multicenter evaluation of whether gender dimorphism affects survival after trauma. Am J Surg. 2001;181(4):297-300.

23. Weniger M, Angele MK, Chaudry IH. The role and use of estrogens following trauma. Shock. 2016;46(1):4-11.

24. Fish EN. The X-files in immunity: sex-based differences predispose immune responses. Nature Rev Immunol. 2008; 8(9):737-744.

25. Jaillon S, Berthenet K, Garlanda C. Sexual Dimorphism in Innate Immunity. Clin Rev Allergy Immunol. 2019; 56:308-321.

26. Fischinger S, Boudreau CM, Butler AL, Streeck H, Alter G. Sex differences in vaccine-induced humoral immunity. Semin Immunopathol. 2019; 41:239-249.

27. Simon B, Kundi M, Puchhammer-Stockl E Association of HCMV specific IgG subclass antibody levels with gender and age. Exp Gerontol 2013; 48:472-475.

28. Müller $\mathrm{C}$ et al The role of sex and weight on rituximab clearance and serum elimination half-life in elderly patients with DLBCL. Blood. 2012; 119:3276-3284.

29. Ruggieri A, Anticoli S, D’Ambrosio A, Giordani L, Viora $M$. The influence of sex and gender on immunity, infection and vaccination. Ann Ist Super Sanita. 2016. 52:198-204.

30. Sankaran-Walters S, Macal M, Grishina I, Nagy L, Goulart L, Coolidge K, Li J, Fenton A, Williams T, Miller MK, Flamm J, Prindiville T, George M, Dandekar S. Sex differences matter in the gut: effect on mucosal immune activation and inflammation. Biol Sex Differ. 2013; 4:10. doi: 10.1186/2042-6410-4-10.

31. Ljungman P, Brandan R. Factors influencing cytomegalovirus seropositivity in stem cell transplant patients and donors. Haematologica. 2007 Aug;92(8):1139-42.

32. Furman D. Sexual dimorphism in immunity: improving our understanding of vaccine immune responses in men. Expert Rev Vaccines. 2015 Mar;14(3):461-71.

33. Hirsch HH, Randhawa P, Practice ASTIDCo. BK polyomavirus in solid organ transplantation. American journal of transplantation: official journal of the American Society of Transplantation and the American Society of Transplant Surgeons. 2013; 13(Suppl 4):179-188.

34. Freeman RB, Paya C, Pescovitz MD, et al. Risk factors for cytomegalovirus viremia and disease developing after prophylaxis in high-risk solid-organ transplant recipients. Transplantation. 2004; 78(12):1765-1773.
35. Perrottet N, Csajka C, Pascual M, et al. Population pharmacokinetics of ganciclovir in solid-organ transplant recipients receiving oral valganciclovir. Antimicrob Agents Chemother. 2009; 53(7):3017-3023.

36. Inamoto Y, Kimura F, Kanda J, Sugita J, Ikegame K, Nakasone H, Nannya Y, Uchida N, Fukuda T, Yoshioka K, Ozawa Y, Kawano I, Atsuta Y, Kato K, Ichinohe T, Inoue M, Teshima T.. Comparison of graft-versus-host disease-free, relapse-free survival according to a variety of graft sources: antithymocyte globulin and single cord blood provide favorable outcomes in some subgroups. Haematologica. 2016; 101(11):1592-1602.

37. Locatelli F, Uderzo C, Dini G, Zecca M, Arcese W, Messina C, Andolina M, Miniero R, Porta F, Rovelli A, et al. Graftversus-host disease in children: the AIEOP-BMT Group experience with Cyclosporin A. Bone Marrow Transplant 1993;12(6):627-633.

38. Gaziev D, Polchi P, Galimberti M, Angelucci E, Giardini C, Baronciani D, Erer B, Lucarelli G. Graft-versus-host disease after bone marrow transplantation for thalassemia: an analysis of incidence and risk factors. Transplantation 1997, 63 (6), 854-60.

39. Garming-Legert K, Remberger M, Ringdén O, Hassan M, Dahllöf G. Long-term salivary function after conditioning with busulfan, fractionated or single-dose TBI. Oral Dis. 2011; 17 (7): 670-676.

40. Confer DL, Abress LK, Navarro W, Madrigal A. Selection of adult unrelated hematopoietic stem cell donors: beyond HLA. Biol Blood Marrow Transplant. 2010;16(1 Suppl):S8-S11.

41. Solh MM, Bashey A, Solomon SR, Morris LE, Zhang X, Brown S, Holland HK.. Long term survival among patients who are disease free at 1-year post allogeneic hematopoietic cell transplantation: a single center analysis of 389 consecutive patients. Bone Marrow Transplant. 2018; 53(5): 576-583.

42. Özen $M$, Üstün C, Öztürk B, Topçuoğlu P, Arat M, Gündüz M, Atilla E, Bolat G, Arslan Ö, Demirer T, Akan H, İlhan O, Beksa M, Gürman G, Özcan M. Allogeneic transplantation in chronic myeloid leukemia and the effect of tyrosine kinase inhibitors on survival: a quasi-experimental study. Turk J Haematol. 2017, 34(1), 16-26.

43. Kako S, Izutsu K, Kato K, Kim S-W, Mori T, Fukuda T, Kobayashi N, Taji H, Hashimoto H, Kondo T, Sakamaki H, Morishima Y, Kato K, Suzuki R, Suzumiya J, et al.. The role of hematopoietic stem cell transplantation for relapsed and refractory Hodgkin lymphoma Am J Hematol ,2015, 90 (2), 132-138.

44. Schmid C, Labopin M, Nagler A, Bornhäuser M, Finke J, Fassas A, Volin L, Gürman G, Maertens J, Bordigoni P, Holler E, Ehninger G, Polge E, Gorin N-C, Kolb H-J, Rocha V, EBMT Acute Leukemia Working Party. Donor lymphocyte infusion in the treatment of first hematological relapse after allogeneic stem-cell transplantation in adults with acute myeloid leukemia: a retrospective risk factors analysis and comparison with other strategies by the EBMT acute leukemia Working Party. J Clin Oncol, 2007;25 (31), 4938-4945. 
45. Gratwohl A, Hermans J, Niederwieser D, van Biezen A, van Houwelingen HC, Apperley J; Chronic Leukemia Working Party of the European Group for Blood and Marrow Transplantation EBMT. Female donors influence transplant-related mortality and relapse incidence in male recipients of sibling blood and marrow transplants. Hematol J. 2001;2(6):363-370.

46. OKunewick JP, Kociban DL, Machen LL, Buffo MJ. Effect of donor and recipient gender disparities on fatal graft-vs.host disease in a mouse model for major histocompatibility complex-matched unrelated-donor bone marrow transplantation. Exp Hematol 1993; 21(12): 1570-1576.

47. Miklos DB, Miklos, Kim HT, Zorn E, Hochberg EP, Guo L, Mattes-Ritz A, Viatte S, Soiffer RJ, Antin JH, Ritz J. Antibody response to DBY minor histocompatibility antigen is induced after allogeneic stem cell transplantation and in healthy female donors. Blood. 2004; 103(1):353-359.

48. Randolph SS, Gooley TA, Warren EH, Appelbaum FR, Riddell SR. Female donors contribute to a selective graft-versus-leukemia effect in male recipients of HLAmatched, related hematopoietic stem cell transplants. Blood. 2004;103(1):347-352.

49. Alhashim N, Aljurf M, Hassanein M, Chaudhri N, Hashmi S, El-Gohary G, Alsharif F, Alsermani M, Alhumaid M, Al Beihany A, Shaheen M, Hanbali A, Alfraih F, Mohamed S, Alzahrani H, Elhassan T, Eldali A, Rasheed W, Ahmed S, Almohareb F, El Fakih R. Extramedullary relapses after allogeneic stem cell transplantation for acute myeloid leukemia: clinical characteristics, incidence, risk factors and outcomes. Bone Marrow Transplant, 2018; 53 (7), 838-843.

50. Ayuk F, Beelen DW, Bornhäuser M, Stelljes M, Zabelina T, Finke J, Kobbe G, Wolff D, Wagner EM, Christopeit M, Schmid C, Ottinger H, Groth C, Faul C, Bertz H, Rachlis E, Wolschke C, Schetelig J, Horn PA, Mytilineos J, Guellstorf M, Kelsch R, Fleischhauer K, Kröger N, Bethge W. Relative impact of HLA matching and non-HLA donor characteristics on outcomes of allogeneic stem cell transplantation for acute myeloid leukemia and myelodysplastic syndrome. Biol Blood Marrow Transplant. 2018;24(12):2558-2567.

51. Hubbard W, Keith J, Berman J, Miller M, Scott C, Peck C, et al. 17alpha-ethynylestradiol-3-sulfate treatment of severe blood loss in rats. J Surg Res. 2015;193(1):355-360.

52. Suzuki T, Shimizu T, Yu HP, Hsieh YC, Choudhry MA. Bland KI, et al. 17 beta-estradiol administration following trauma-hemorrhage prevents the increase in Kupffer cell cytokine production and MAPK activation predominately via estrogen receptor-alpha. Surgery. 2006;140(2):141-148.

53. Wu CC, Chang CY, Chang ST, Chen SH. 17beta-estradiol accelerated renal tubule regeneration in male rats after ischemia/reperfusion-induced acute kidney injury. Shock. 2016;46(2):158-163.

54. Angele MK, Pratschke S, Hubbard WJ, Chaudry IH. Gender differences in sepsis: cardiovascular and immunological aspects. Virulence. 2014;5(1):12-19.
55. Goldberg GL, King CG, Nejat RA, Suh DY, Smith OM, Bretz JC, Samstein RM, Dudakov JA, Chidgey AP, ChenKiang S, Boyd RL, van den Brink MR. Luteinizing hormone-releasing hormone enhances $\mathrm{T}$ cell recovery following allogeneic bone marrow transplantation. J Immunol, 2009,182 (9), 5846-5854. 


\title{
Фактор пола при трансплантации гемопоэтических стволовых клеток
}

\author{
Алексей Б. Чухловин \\ НИИ детской онкологии, гематологии и трансплантологии им. Р. М. Горбачевой, Первый Санкт-Петербургский \\ государственный медицинский университет им. акад. И. П. Павлова, Санкт-Петербург, Россия
}

\section{Резюме}

Имеется огромное число исследований, касающихся метаболических, иммунологических и других различий между мужским и женским организмом, связанных с их различным гормональным и физиологическим фоном. Однако лишь немногие работы посвящены половым различиям в числе донорских гемопоэтических клеток для трансплантации гемопоэтических стволовых клеток (ТГСК), фармакокинетике цитостатических препаратов, используемых для кондиционирующей терапии и иммуносупрессоров для профилактики РТПХ, а также различий в плане частых посттрансплантационных осложнений. На основании предыдущих работ можно предположить о ряде различий, которые могут иметь значение для оценки результатов РТПХ: (1) Повышенные количества CD34+ клеток в трансплантатах от мужчин, по сравнению с донорами-женщинами; (2) Метаболизм цитостатических препаратов у женщин имеет тенденцию к сниженному клиренсу и повышенной скорости метаболической модификации в связи с повышенной активности цитохромов СYР3А, наряду со сниженным оттоком препаратов из клеток-мишеней, что предполагает более выраженное накопление активных цитостатических метаболитов в женском организме; (3) Более эффективный и стабильный гуморальный иммунный ответ у женщин по сравнению с мужчинами может выражаться, как в лучшем антиинфекционном ответе, так и повышенном риске хронической РТПХ у женщин после аллогенной ТГСК; (4) Пациенты мужского пола с некоторыми злокачественными заболеваниями системы крови после алло-ТГСК более склонны к посттрансплантационным рецидивам, хотя сообщают и иные результаты; (5) Повышенный риск острой РТПХ у мужчин имеется в случаях алло-ТГСК от доноров-женщин. Вопрос о наличии эффекта «трансплантат против лейкоза» в этой ситуации остается открытым. В целом, эстрогены, видимо, являются наиболее вероятной причиной половых различий при оценке ТГСК-ассоциированных рисков. Тем не менее, модифицирующая роль половых стероидных гормонов здесь изучена недостаточно, и она должна изменяться в зависимости от возраста пациентов. Поэтому реальная значимость половых различий при ТГСК заслуживает дальнейших углубленных исследований на больших базах данных.

\section{Ключевые слова}

Трансплантация гемопоэтических стволовых клеток, половые различия, фармакокинетика, иммунный ответ, РТПХ, рецидивы, выживаемость, эстрогены, исходы. 